\title{
ARTICLE
}

\section{Oceanographic conditions and marine mammals: identifying a potential relationship in the coastal region of the Mexican Central Pacific}

\author{
Condiciones oceanográficas y mamíferos marinos: identificando una posible
} relación en la región costera del Pacífico Central Mexicano

\section{Tadashi Kono-Martínez ${ }^{1}$, Christian D. Ortega-Ortiz ${ }^{*}$, Aramis Olivos-Ortiz ${ }^{2}$, Ernesto Torres-Orozco ${ }^{1}$ and Eduardo González-Rodríguez ${ }^{3}$}

${ }^{1}$ Facultad de Ciencias Marinas, Universidad de Colima, Km 20 Carr. Manzanillo-Barra de Navidad, C.P. 28860, Manzanillo, Col., México. *Corresponding author: christian_ortega@ ucol.mx

${ }^{2}$ Centro Universitario de Investigaciones Oceanológicas, Universidad de Colima, Km 20 Carr. Manzanillo-Barra de Navidad, C.P. 28860, Manzanillo, Col., México

${ }^{3}$ Centro de Investigación Científica y de Educación Superior de Ensenada, Unidad La Paz, Miraflores No. 334 e/ Mulegé y La Paz, C.P. 23050, La Paz, B.C.S., México

Resumen.- Se investigaron las condiciones oceanográficas que podrían influir en la riqueza y distribución de mamíferos marinos en costas del Pacífico Central Mexicano durante el 2011. Las observaciones de mamíferos marinos se realizaron desde dos plataformas de investigación. Se muestrearon mensualmente 6 estaciones, donde se realizaron lances de CTD hasta $100 \mathrm{~m}$ y se tomaron muestras de agua para determinación de nutrientes inorgánicos; y otras 15 estaciones fueron muestreadas solamente durante invierno en una región más amplia. Se utilizaron imágenes de satélite (MODIS-AQUA L2) para obtener valores de temperatura superficial del mar (TSM) y clorofila (Chl-a); y datos de altimetría para identificar estructuras dinámicas de mesoescala en la región. Durante invierno-primavera se encontraron valores altos de salinidad $(34,6)$, valores bajos de nitratos y nitritos $(\sim 3-4$ $\mu \mathrm{M})$, silicatos $(5-7 \mu \mathrm{M})$ y clorofila $\left(\sim 10 \mathrm{mg} \mathrm{m}^{-3}\right)$; como también valores bajos de temperatura $\left(\sim 23,5^{\circ} \mathrm{C}\right)$ y la presencia de giros ciclónicos cerca de la costa. Esto coincidió con la riqueza mayor (de 5 a 9 especies dependiendo la escala espacial) de mamíferos marinos en la zona. La especie dominante fue Megaptera novaeangliae $\left(0,092\right.$ avistamientos $\left.\mathrm{km}^{-1}\right)$, la cual se distribuyó hacia zonas costeras en aguas someras. Durante verano-otoño se registraron valores bajos de salinidad $(32,8)$ y $\mathrm{Chl}-\mathrm{a}\left(0,1 \mathrm{mg} \mathrm{m}^{-3}\right)$. Se detectó una disponibilidad alta de fosfatos $(2,5 \mu \mathrm{M})$, la presencia de giros anticiclónicos y temperaturas altas $\left(\sim 31^{\circ} \mathrm{C}\right)$, coincidiendo con la riqueza más baja (3 especies) de mamíferos marinos. Stenella attenuata fue la especie dominante (0,036 avistamientos $\left.\mathrm{km}^{-1}\right)$, cuyos individuos fueron encontrados distribuidos cerca de las costas de Jalisco y Colima (0-3mn), en aguas someras con una disponibilidad alta de nutrientes inorgánicos. El análisis de componentes principales mostró que la batimetría (99.6\%) fue el principal parámetro que explica la varianza de los datos, por lo que podría potencialmente modular aspectos ecológicos de los mamíferos marinos.

Palabras clave: Estructuras dinámicas de mesoescala, clorofila-a, temperatura superficial del mar, batimetría, mamíferos marinos

\begin{abstract}
The oceanographic conditions that could influence richness and distribution of marine mammal species in the coastal area of the Mexican Central Pacific (MCP) were investigated throughout 2011. Marine mammals observations were obtained from two research platforms. CTD casts were deployed down to $100 \mathrm{~m}$, water samples were taken monthly at six stations for determination of organic nutrients, and another 15 stations were sampled over a wider area only during the winter. Satellite images from MODISAQUA L2 were used to obtain sea surface temperature (SST) and chlorophyll-a (Chl-a) values, likewise altimetry data to identify mesoscale dynamic structures in the region. High salinity values (34.6), low concentrations of nitrates and nitrites $(\sim 3-4 \mu \mathrm{M})$, silicates $(5-7 \mu \mathrm{M})$, Chl-a $\left(\sim 10 \mathrm{mg} \mathrm{m}^{-3}\right)$, and low SST $\left(\sim 23.5^{\circ} \mathrm{C}\right)$ were detected, as well as the presence of cyclonic gyres near the coast during the winter-spring period. This coincided with high marine mammal species richness in the area (from 5 to 9 species depending on spatial scale). The dominant species was Megaptera novaeangliae (0.092 sightings $\left.\mathrm{km}^{-1}\right)$, which was distributed close to the coast in shallow waters. Low salinity (32.8) and Chl-a values $\left(0.1 \mathrm{mg} \mathrm{m}^{-3}\right)$ were detected during the summer-fall period. High phosphate availability $(2.5 \mu \mathrm{M})$, presence of anticyclonic gyres, and high SST $\left(\sim 31^{\circ} \mathrm{C}\right)$ were also found, coinciding with low species richness ( 3 species). The dominant species was Stenella attenuata (0.036 sightings $\mathrm{km}^{-1}$ ); those individuals were found distributed near the Jalisco-Colima coast $(0-3 \mathrm{~nm})$ in shallow waters with high inorganic nutrient availability. The principal components analysis showed that bathymetry $(99.6 \%)$ was the main parameter explaining data variance; this parameter could therefore potentially modulate ecological aspects of marine mammals.
\end{abstract}




\section{INTRODUCTION}

Marine mammals are considered protected species under national and international agreements (e.g., Mexican Norm 059-SEMARNAT-2010 ${ }^{1}$ and IUCN red list ${ }^{2}$ ). They are pelagic animals with biological (breeding and feeding) and ecological (dispersion, distribution, migration, etc.) activities influenced by abiotic factors (Ballance et al. 2006, Laptikhovsky 2009, Rennie et al. 2009) such as the bathymetry, distance to the coast, thermocline depth, temperature, water clarity, primary productivity (chlorophyll- $a$ ), and food availability (Bräger $e t$ al. 2003, Hastie et al. 2003, Danil \& Chivers 2006, Rasmussen et al. 2011). Physical water properties are modulated by several dynamic structures such as gyres (cyclonic and anticyclonic), upwellings, meanders, and filaments, among other systems that are called mesoscale dynamic structures (MDS), based on their size (1-100 km) (Talley et al. 2011). The intensity of MDS in the ocean depends in general on the gravity, density gradients, and wind effort, which produce the re-suspension or sinking of particles and organisms (Linacre et al. 2010). This allows the establishment of complex trophic webs that generate availability of potential prey (Torres-Orozco et al. 2005), leading to the aggregation of top predators such as marine mammals (Rennie et al. 2009).

Fourteen species of marine mammals have been reported (Ortega-Ortiz et al. 2013) in the coastal region of the Mexican Central Pacific (MCP), with high sighting rates of humpback whales (Megaptera novaeangliae) during winter, and of spotted dolphins (Stenella attenuata) throughout the year (Ortega-Ortiz et al. 2011). However, few studies have described the interaction between marine mammals and their environment in coastal and tropical areas such as the MCP region, where oceanographic parameters vary seasonally due to anthropogenic and continental influences as well as to the presence of storms (Salas et al. 2006). This particular zone is located within a dynamic transition zone that generates variability in physico-chemical parameters and the increase of the region's primary productivity (Galicia-Pérez et al. 2006, Kessler 2006, López-Sandoval et al. 2009).

Studies of the interaction between marine mammals and oceanographic parameters of the water column have suggested that MDS are the main factors influencing the presence of cetaceans in northwestern Mexico (La Paz Bay, B.C.S.), where water column mixing and the increase in chlorophyll- $a(\mathrm{Chl}-a)$ concentrations favor the aggregation of potential cetacean prey
(Salvadeo et al. 2009, Pardo et al. 2013). Given these characteristics and the fact that marine mammals are considered 'bio-indicators' because they are sensitive to environmental changes that modify their habitats and/or the distribution/ abundance of their potential prey (Moore 2008). Thus, we hypothesize that the typical variability of oceanographic conditions in the tropical region could influence the occurrence and distribution of marine mammal species, reflecting the environmental quality. The aim of this study was therefore to identify a potential relationship between the oceanographic conditions and the richness and distribution of marine mammal species in the coastal area of the MCP during 2011.

\section{MATERIALS AND METHODS}

\section{STUdy AREA}

This study was conducted mainly in the coastal area of Jalisco and Colima, Mexico (between $19^{\circ} 35^{\prime}$ and $18^{\circ} 00^{\prime} \mathrm{N}$, and $103^{\circ} 30^{\prime}$ and $\left.105^{\circ} 25^{\prime} \mathrm{W}\right)$, where the continental shelf ( $200 \mathrm{~m}$ isobaths) extends $\sim 13 \mathrm{~km}$ from the coast (Fig. 1). The area is influenced by the California Current (CC) flowing southwards during the winter-spring period, and by the Mexican Coastal Current (MCC) flowing northwards during the summer-fall period, with the highest intensity during the fall season (Wyrtki 1967, Kessler 2006, Lavín et al. 2006a, Pantoja et al. 2012). Some authors have concluded that the topography and physiographic traits of the coastline promote the formation of MDS over the continental shelf in this region (Galicia-Pérez et al. 2006, Salas et al. 2006).

\section{OCEANOGRAPHIC PARAMETERS COLLECTION}

Due to the different effort in the surveys, we separated in two sampling categories: coastal surveys and a mesoscale survey, which covered a wider area.

\section{Coastal surveys}

Monthly samples were obtained at six stations located off the southern Jalisco and Colima coast during the periods of JanuaryFebruary and April-December 2011 from a 26 feet long outboard motor vessel. Three stations were located $1.8 \mathrm{~km}$ (1 $\mathrm{nm}$ ) from the coast (coastal transect), and the other three were located $9.3 \mathrm{~km}(5 \mathrm{~nm})$ from the coast (oceanic transect) (Fig. $1)$.

\footnotetext{
${ }^{1}$ NORMA Oficial Mexicana NOM-059-SEMARNAT-2010. Protección ambiental-Especies nativas de México de flora y fauna silvestresCategorías de riesgo y especificaciones para su inclusión, exclusión o cambio. Lista de especies en riesgo. <http://www.profepa.gob.mx/ innovaportal/file/435/1/NOM_059_SEMARNAT_2010.pdf>

${ }^{2}$ IUCN Global Species Programmed Red List Unit. The IUCN Red List of Threatened Species. IUCN, Cambridge. <http://www.iucnredlist.org/>
} 


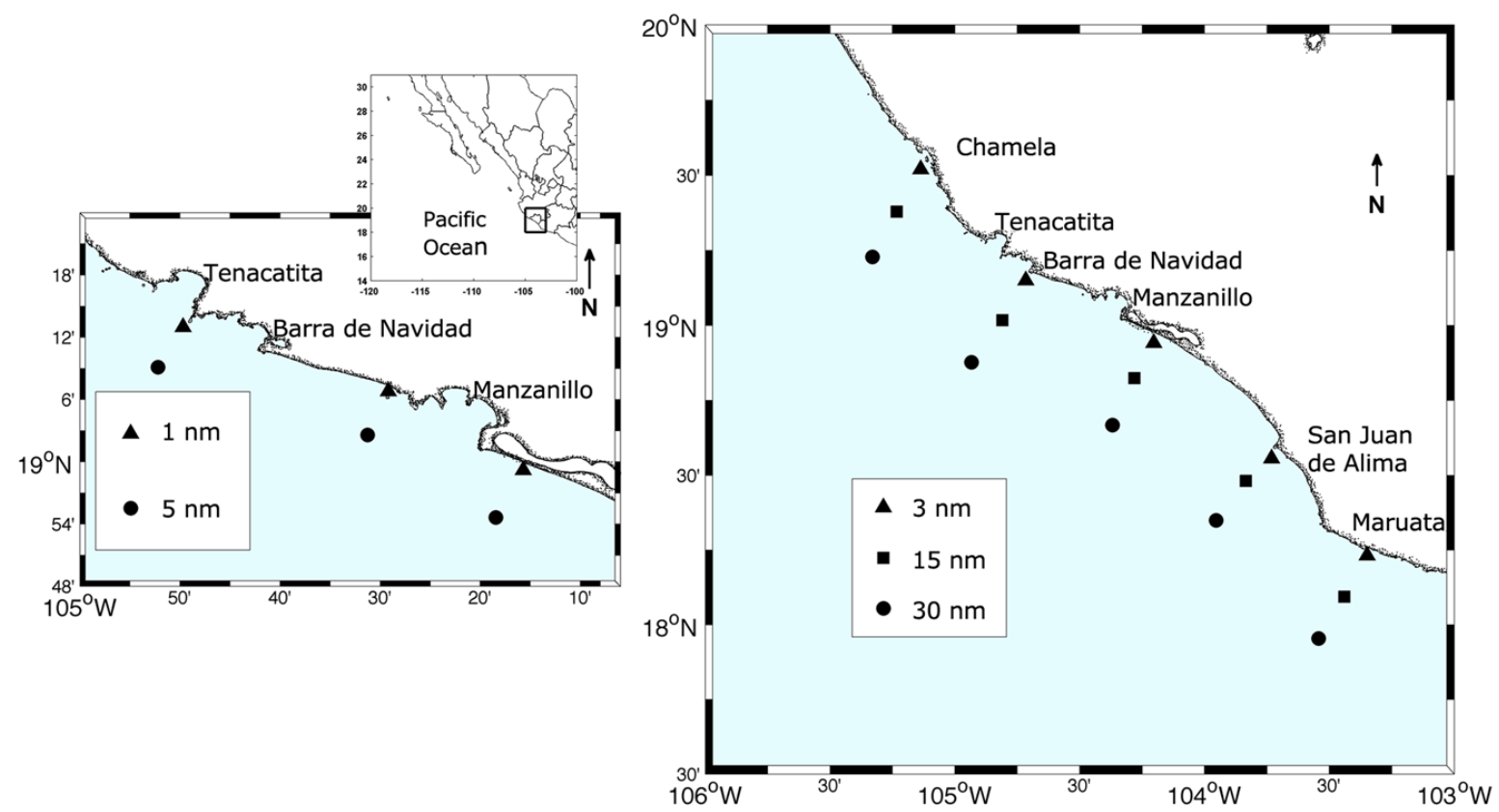

Figure 1. Location of the sampling stations within the M exican Central Pacific. Stations sampled during surveys conducted from a small boat off the Jalisco-Colima coast (left). Stations sampled during the mesoescale survey during March 2011 (right)/ Posición de las estaciones de muestreo en el Pacífico central mexicano. Estaciones muestreadas durante los cruceros realizados en embarcación pequeña en la costa de Jalisco-Colima (izquierda). Estaciones muestreadas durante el crucero de mesoescala durante marzo 2011 (derecha)

\section{Mesoscale Survey}

In order to corroborate a potential pattern in distribution-richness of marine mammals related with oceanographic parameters, during winter (at March), the expected period with a major rate of sighting of marine mammals (Ortega-Ortiz et al. 2013), a survey in a wider area was conducted using a 42 feet long vessel. Five transects were established parallel to the coast, each one comprising three stations located $5.5 \mathrm{~km}(3 \mathrm{~nm}$, coastal), $28 \mathrm{~km}$ (15 nm, intermediate), and $56 \mathrm{~km} \mathrm{(30} \mathrm{nm,}$ oceanic) from the coast (Fig. 1).

Oceanographic parameters that describe productivity/stability conditions through the water column, such as temperature, salinity, mixed layer depth, nutrients, and chlorophyll- $a$, were determined during coastal as well as mesoscale survey. CTD (Sontek CastAway) profiles were constructed down to a 100 $\mathrm{m}$ depth at the 21 sampling stations (coastal surveys and mesoscale survey). Water samples $(100 \mathrm{ml})$ were taken at 0 , 25 , and $50 \mathrm{~m}$ depths using $5 \mathrm{~L}$ Niskin bottles. These samples were frozen until later analysis of inorganic nutrient concentration (nitrates and nitrites, phosphates, and silicates); these analyses were carried out using a continuous flow auto-analyzer (Skalar
San Plus), following methods proposed by Grasshoff et al. (1983). The mixed layer depth was calculated following methods proposed by Kara et al. (2000).

In addition, to describe oceanographic conditions in a wider scale for MCP region, level 2 images ( $1 \mathrm{~km}$ and 1 day spatial/ time resolution) of sea surface temperature (SST) and Chl- $a$ were obtained from the MODIS Aqua sensor (National Aeronautics and Space Administration) $)^{3}$. Monthly images with $>70 \%$ coverage of SST and Chl- $a$ concentration were later extracted to identify mesoscale dynamic structures in the MCP region. Altimetry data from the AVISO (Aviso User Service, France $)^{4}$ program were also processed to identify circulation patterns (with $1 / 3^{\circ}$ resolution) in the area to analyze the satellite data in integrated plots using ${ }^{\circledR}$ MATLAB ver. 7.11 software (The MathWorks, Inc.). It was additional information to use as reference by integrating with the coastal information. The statistical analysis was also performed using ${ }^{\circledR}$ MATLAB ver. 7.11 software. Data did not have a normal distribution, and the non-parametric tests Kruskal-Wallis (H) and Dunn (Q) were therefore used with a 0.05 significance level.

${ }^{3}$ NASA, Gene C. Feldman.<https://oceancolor.gsfc.nasa.gov/data/aqua/>

${ }^{4}<$ http://www.aviso.altimetry.fr/en/data.html> 


\section{MARINe MAMMAL SIGHTINGS}

A path was surveyed between sampling stations during the coastal and mesoscale surveys to record marine mammal sightings, at a speed between 7 and 9 knots. Sightings were detected by three observers (at the bow, port, and starboard) using Fujinon ${ }^{\circledR} 7 \times 50$ binoculars. The geographical position, species, and number of animals of each sighting were recorded. The unit effort was estimated as the total distance travelled $(\mathrm{km})$ during which marine mammals were searched for. Marine mammal sightings were standardized by calculating the sighting rate (SR) with the following equation:

$$
S R=n / e
$$

where $n$ is the number of sightings and $e$ is the effort in kilometers (Kiszka et al. 2007). The sighting rate during coastal surveys was calculated for a) each season (winter: from January to February, spring: from April to June, summer: from July to September, and fall: from October to December), and for b) each month during 2011. The sighting rate during the mesoscale survey was additional information to integrate with the coastal information to carry out an exhaustive discussion about our results.

\section{RELATIONSHIP BETWEEN OCEANOGRAPHIC PARAMETERS} AND DISTRIBUTION-RICHNESS OF MARINE MAMMALS

In order to identify a potential relationship between marine mammals and oceanographic data a principal components analysis (PCA) was used, following the method proposed by Clarke \& Warwick (2001). The marine mammal data used for these analyses were only the most frequently recorded species in the region (Ortega-Ortiz et al. 2011, 2013).

\section{Results}

\section{Sea Surface Temperature and salinity during COASTAL SURVEYS}

Sea surface temperature (SST) varied significantly between seasons $\left(\mathrm{H}_{66,3}=37.83, P<0.001\right)$. Minimum values $\left(23.5^{\circ} \mathrm{C}\right)$ were recorded during the winter-spring period, and maximum values $\left(31.1^{\circ} \mathrm{C}\right)$ were recorded during the summer season, with temperatures decreasing $\left(23.9^{\circ} \mathrm{C}\right)$ in the middle of the fall season (Table 1). Spatial variation of temperature, at the surface as well as at $50 \mathrm{~m}$ depth, was minimal $\left(\sim 1^{\circ} \mathrm{C}\right)$ during winter-spring $\left(\mathrm{H}_{30,5}=0.95, P>0.001\right)$; but warmer temperatures $\left(27.5^{\circ} \mathrm{C}\right)$ were recorded at the surface at the southern oceanic station (Table 2). Spatial variation of temperature was also minimal $\left(\mathrm{H}_{36,5}=0.62, P>0.001\right)$ during the summer-fall period, with a maximum value $\left(29.2^{\circ} \mathrm{C}\right)$ at the surface at the intermediate oceanic station (Table 2 ).

Salinity varied significantly between seasons $\left(\mathrm{H}_{663}=25.58\right.$, $P<0.001$ ), and had opposite patterns to Temperature: with maximum values of 34.6 occurring during the winter-spring period, and decreasing to minimum values of 32.8 during the summer-fall period (Table 1). Spatial variation of salinity was low $(0.3)\left(\mathrm{H}_{66,5}=0.84, P>0.001\right)$ during the winter-spring and summer-fall periods (0.5). The lowest salinity (33.4) was recorded at the surface at the coastal southern station, whereas the highest salinity (33.9) was recorded at the surface at the oceanic northern station (Table 2).

Table 1. Seasonal variability of oceanographic parameters and mixed layer depth obtained from coastal surveys in the Mexican Central Pacific during 2011. Mean and Rank values for temperature are included / Variación estacional de parámetros oceanográficos y capa de mezcla obtenidos de los cruceros costeros en el Pacífico central mexicano durante el 2011. Se incluyen valores medios y rango de la temperatura

\begin{tabular}{|c|c|c|c|c|c|c|c|c|c|c|c|}
\hline & \multicolumn{2}{|c|}{ Winter } & \multicolumn{3}{|c|}{ Spring } & \multicolumn{3}{|c|}{ Summer } & \multicolumn{3}{|c|}{ Fall } \\
\hline & Jan & $\mathrm{Feb}$ & Apr & May & Jun & Jul & Aug & Sep & Oct & Nov & Dec \\
\hline \multirow{2}{*}{ Temperature $\left({ }^{\circ} \mathrm{C}\right)$} & 24.4 & 25.2 & 26.0 & 29.1 & 29.70 & 30.0 & 29.77 & 30.7 & 29.7 & 26.3 & 27.3 \\
\hline & $(23.5-25.3)$ & $(24.2-26.6)$ & $(25-27.1)$ & $(28-29.5)($ & $(29.1-30.3)$ & $(29.8-30.2)$ & $(29.4-30.2)$ & $(30.4-31.1)$ & $(29.3-30.1)$ & $(23.9-27.8)$ & $(26.3-27.6)$ \\
\hline Salinity & 34.3 & 34.2 & 34.5 & 34.6 & 33.6 & 33.0 & 33.4 & 33.5 & 32.8 & 34.4 & 34.3 \\
\hline $\mathrm{NO}_{3}^{-}+\mathrm{NO}_{2}^{-}(\mu \mathrm{M})$ & 4.7 & 4.6 & 4.3 & 3.1 & 4.0 & 4.2 & 4.3 & 6.3 & 3.6 & 3.8 & 8.4 \\
\hline $\mathrm{PO}_{4}^{-3}(\mu \mathrm{M})$ & 1.4 & 1.0 & 0.9 & 0.7 & 0.7 & 1.1 & 0.6 & 2.2 & 2.4 & 2.5 & 1.0 \\
\hline $\mathrm{SiO}_{2}(\mu \mathrm{M})$ & 6.6 & 7.4 & 6.7 & 5.9 & 5.2 & 4.6 & 5.1 & 7.2 & 7.3 & 4.6 & 8.2 \\
\hline $\begin{array}{l}\text { Mean mixed layer } \\
\text { depth (m) }\end{array}$ & 7 & 6 & 5 & 20 & 23 & 18 & 32 & 22 & 10 & 5 & 13 \\
\hline
\end{tabular}


Table 2. Spatial variability of oceanographic parameters obtained from coastal surveys in the Mexican Central Pacific during the cold (winter-spring) and warm periods (summer-fall) of 2011. Mean and rank values for temperature are included. Coast= coastal station. Ocean= oceanic station. 1= Southern station. 2= Intermediate station. 3= Northern station (Left map from Fig. 1) / Variación estacional de parámetros oceanográficos obtenidos de los cruceros costeros en el Pacífico central mexicano durante los periodos frío (invierno-primavera) y cálido (verano-otoño) de 2011. Se incluyen valores medios y rango de la temperatura. Coast= estaciones costeras. Ocean= estaciones oceánicas. $1=$ estaciones del sur. $2=$ estaciones intermedias. $3=$ estaciones del norte (mapa a la izquierda de la Fig. 1)

\begin{tabular}{|c|c|c|c|c|c|c|c|c|c|c|c|c|c|c|c|c|c|c|}
\hline \multirow[b]{2}{*}{ Winter-Spring period } & \multicolumn{3}{|c|}{ Coast 1} & \multicolumn{3}{|c|}{ Coast 2} & \multicolumn{3}{|c|}{ Coast 3} & \multicolumn{3}{|c|}{ Ocean 1} & \multicolumn{3}{|c|}{ Ocean 2} & \multicolumn{3}{|c|}{ Ocean 3} \\
\hline & & & & & & & & & & & & & & & & & & \\
\hline Depth (m) & 0 & 25 & 50 & 0 & 25 & 50 & 0 & 25 & 50 & 0 & 25 & 50 & 0 & 25 & 50 & 0 & 25 & 50 \\
\hline Temperature $\left({ }^{\circ} \mathrm{C}\right)$ & $\begin{array}{c}26.6 \\
(23.8-29.8)\end{array}$ & $\begin{array}{c}22.8 \\
(17.6-28.7)\end{array}$ & $\begin{array}{c}19.2 \\
(15.8-25.3)\end{array}$ & $\begin{array}{c}26.8 \\
(24.1-30)\end{array}$ & $\begin{array}{c}23.4 \\
(17.9-29.5)\end{array}$ & $\begin{array}{c}20.6 \\
(14.4-29.4)\end{array}$ & $\begin{array}{c}26.3 \\
(23.5-29.6)\end{array}$ & $\begin{array}{c}22.3 \\
(15.8-29.2)\end{array}$ & $\begin{array}{c}20 \\
(14.6-28.1)\end{array}$ & $\begin{array}{c}27.5 \\
(24.7-30.3)\end{array}$ & $\begin{array}{c}23.5 \\
(19.7-30.1)\end{array}$ & $\begin{array}{c}19.3 \\
(16.4-23.1)\end{array}$ & $\begin{array}{c}27 \\
(25.4-29.3)\end{array}$ & $\begin{array}{c}23.4 \\
(18.7-29.6)\end{array}$ & $\begin{array}{c}20 \\
(15.9-27.7)\end{array}$ & $\begin{array}{c}27.3 \\
(25.1-29.5)\end{array}$ & $\begin{array}{c}24.1 \\
(20.3-29.3)\end{array}$ & $\begin{array}{c}20.4 \\
(16-28.9)\end{array}$ \\
\hline Salinity & 34.4 & 34.4 & 34.4 & 34.1 & 34.2 & 34.3 & 34.1 & 34.3 & 34.4 & 34.4 & 34.4 & 34.5 & 34.2 & 34.3 & 34.5 & 34.2 & 34.3 & 34.4 \\
\hline $\mathrm{NO}_{3}^{-}+\mathrm{NO}_{2}^{-}(\mu \mathrm{M})$ & 3.3 & 6.7 & 10.6 & 5.1 & 7.8 & 10.5 & 4.4 & 6.7 & 10.8 & 4.9 & 7.0 & 12.6 & 2.7 & 6.9 & 12.4 & 4.8 & 6.5 & 12.5 \\
\hline $\mathrm{PO}_{4}^{-3}(\mu \mathrm{M})$ & 1 & 1.6 & 1.9 & 1 & 1.6 & 1.9 & 0.8 & 1.1 & 2 & 1.3 & 1.5 & 2 & 0.9 & 1.2 & 1.6 & 0.9 & 1.4 & 2 \\
\hline $\mathrm{SiO}_{2}(\mu \mathrm{M})$ & 6.7 & 9 & 18.1 & 5.1 & 9 & 17.9 & 6.7 & 10.2 & 18 & 7.1 & 9.9 & 18 & 5.8 & 9.4 & 16.9 & 7 & 8.1 & 17 \\
\hline \multicolumn{19}{|l|}{ Summer-Fall period } \\
\hline Depth (m) & 0 & 25 & 50 & 0 & 25 & 50 & 0 & 25 & 50 & 0 & 25 & 50 & 0 & 25 & 50 & 0 & 25 & 50 \\
\hline Temperature $\left({ }^{\circ} \mathrm{C}\right)$ & $\begin{array}{c}29.1 \\
(27.2-30.5)\end{array}$ & $\begin{array}{c}26.3 \\
(22-30.2)\end{array}$ & $\begin{array}{c}20 \\
(16.3-29.3)\end{array}$ & $\begin{array}{c}28.7 \\
(25.8-31.1)\end{array}$ & $\begin{array}{c}27.4 \\
(23.3-30.3)\end{array}$ & $\begin{array}{c}20.1 \\
(15.7-29.1)\end{array}$ & $\begin{array}{c}27.9 \\
(23.9-30.4)\end{array}$ & $\begin{array}{c}26.1 \\
(20.8-30)\end{array}$ & $\begin{array}{c}20 \\
(15.9-25.3)\end{array}$ & $\begin{array}{c}29.1 \\
(27.6-30.7)\end{array}$ & $\begin{array}{c}26.2 \\
(19-30)\end{array}$ & $\begin{array}{c}21.3 \\
(16.2-27.8)\end{array}$ & $\begin{array}{c}29.2 \\
(25.4-29.3)\end{array}$ & $\begin{array}{c}25.7 \\
(19.7-30)\end{array}$ & $\begin{array}{c}20.5 \\
(15.9-28.5)\end{array}$ & $\begin{array}{c}28.5 \\
(25.2-30.6)\end{array}$ & $\begin{array}{c}26 \\
(21.1-30.3)\end{array}$ & $\begin{array}{c}20.7 \\
(15.5-26.9\end{array}$ \\
\hline Salinity & 33.4 & 33.9 & 34.4 & 33.7 & 34 & 34.3 & 33.7 & 34.1 & 34.6 & 33.8 & 34 & 34.5 & 33.7 & 34.1 & 34.5 & 33.9 & 34.2 & 34.6 \\
\hline $\mathrm{NO}_{3}^{-}+\mathrm{NO}_{2}^{-}(\mu \mathrm{M})$ & 5 & 8.2 & 17.2 & 5.2 & 8.7 & 17.2 & 7.1 & 7.6 & 14 & 5.3 & 8.4 & 16.9 & 4.4 & 8.4 & 18 & 4.8 & 8.3 & 16.6 \\
\hline $\mathrm{PO}_{4}^{-3}(\mu \mathrm{M})$ & 1.6 & 2 & 2.5 & 1.9 & 2.1 & 2.6 & 2.1 & 2.6 & 2.9 & 1.7 & 2.5 & 2.9 & 1.6 & 1.8 & 2.9 & 1.6 & 2.4 & 2.7 \\
\hline $\mathrm{SiO}_{2}(\mu \mathrm{M})$ & 6.6 & 9 & 18.1 & 5.9 & 9.3 & 18.6 & 8.6 & 8.3 & 16.2 & 5.9 & 9.1 & 18.2 & 6.1 & 8.7 & 17.8 & 6 & 9.7 & 18.3 \\
\hline
\end{tabular}

\section{NUTRIENTS DURING COASTAL SURVEYS}

Low concentrations of nitrates and nitrites (range: from 3.1 to $4.7 \mu \mathrm{M}$ ), phosphates (range: from 0.7 to $1.4 \mu \mathrm{M}$ ), and silicates (range: from 5.2 to $7.4 \mu \mathrm{M}$ ) (Table 1) were recorded during the winter-spring period. Nutrient concentrations were higher during the summer-fall period (range: from 3.6 to $8.4 \mu \mathrm{M}$ ); phosphate concentrations ranged between 0.6 and $2.5 \mu \mathrm{M}$, and silicate concentrations ranged between 4.6 and $8.2 \mu \mathrm{M}$ (Table 1).

The spatial variation of nutrients was not statistically significant $\left(\mathrm{H}_{30.5}=3.49, P>0.001\right)$ during winter-spring; however, maximum values of nitrate and nitrite $(12.5-12.6 \mu \mathrm{M})$ were measured at the northern and southern oceanic stations. There was no spatial variability in the phosphate and silicate concentrations during this period; values were similar between stations and depths (Table 2).

There was no spatial variability $\left(\mathrm{H}_{36,5}=1.19, P>0.001\right)$ during the summer-fall period; however, high concentrations of mainly nitrates, nitrites, and phosphates were recorded at the coastal northern station at almost all sampled depths (Table 2).

\section{Mixed Layer during COASTAL SURVEYS}

The water column was stratified with a well-defined mixed layer (ML) in the upper $10 \mathrm{~m}$ during winter and at the beginning of the spring season. The ML deepened to 20 and $23 \mathrm{~m}$ around the middle of the spring season (Table 1). The MLdeepened to $18 \mathrm{~m}$ at the beginning of the summer season, then deepened further to $32 \mathrm{~m}$ at the middle of the season, and shoaled to 22 $\mathrm{m}$ at the end of this same season. The ML was thinner during the fall season, decreasing at a depth of $10 \mathrm{~m}$; by the end of the fall season the ML was situated at $13 \mathrm{~m}$ depth, and the water column was again stratified (Table 1).

\section{OCEANographic Parameters during the Mesoscale} SURVEY

The sea surface temperature did not vary significantly between the coastal (range: $25.4-27.5^{\circ} \mathrm{C}$ ), intermediate (range: 23.6 $27.8^{\circ} \mathrm{C}$ ), and oceanic stations (range: $24.8-26.6^{\circ} \mathrm{C}$ ) during the mesoscale survey; this pattern was similar at 25 and $50 \mathrm{~m}$ depth. Salinity values were similar at all stations, and nutrients did not show spatial differences, only silicates had higher values (28$33.1 \mu \mathrm{M})$ at the coastal stations, mainly at $25 \mathrm{~m}$ depth $(33.1$ $\mu \mathrm{M})$ (Table 3). The water column was stratified and with a welldefined mixed layer (ML) in the upper $15 \mathrm{~m}$.

\section{Sea surface temperature, Chlorophyll-a, and ALTIMETRY IN THE STUDY AREA}

A SST of $22^{\circ} \mathrm{C}$ and Chl- $a$ concentrations of $10 \mathrm{mg} \mathrm{m}^{-3}$ were recorded near the coast during the winter-spring period in the northern part of the study area (Figs. 2 and 4). Similar values were also recorded in the oceanic zone, where a cyclonic gyre was observed (Fig. 2a). By the middle of the winter-spring period the circulation pattern changed from south to north, warm waters were recorded $\left(31^{\circ} \mathrm{C}\right)$ (Fig. 2e), and the Chl- $a$ concentration decreased to $1 \mathrm{mg} \mathrm{m}^{-3}$ (Fig. 4e).

During the summer-fall period the circulation pattern consisted in water flow towards the northwest, with temperatures of $31^{\circ} \mathrm{C}$ and a minimal Chl- $a$ concentration of $\sim 0.1 \mathrm{mg} \mathrm{m}^{-3}$ 
Table 3. Spatial variability of oceanographic parameters obtained from the mesoscale survey (March 2011) in the Mexican Central Pacific. Number 1 refer the station in the most southern position and 5 is for the station in the most northern position (right map from Fig. 1) / Variación estacional de parámetros oceanográficos obtenidos en el crucero de mesoescala (marzo 2011) en el Pacífico central mexicano. El número 1 se refiere a la estación en la posición más sureña y el 5 para la estación en la posición más norteña (mapa a la derecha de la Fig. 1)

\begin{tabular}{|c|c|c|c|c|c|c|c|c|c|c|c|c|c|c|c|c|}
\hline \multirow{2}{*}{$\begin{array}{l}\text { Station/ Depth } \\
\text { (m) }\end{array}$} & \multicolumn{3}{|c|}{$\begin{array}{c}\text { Temperature } \\
\left({ }^{\circ} \mathrm{C}\right)\end{array}$} & \multicolumn{3}{|c|}{ Salinity } & \multicolumn{3}{|c|}{$\begin{array}{l}\text { Nitrates and } \\
\text { nitrites }(\mu \mathrm{M})\end{array}$} & \multicolumn{3}{|c|}{$\begin{array}{l}\text { Phosphates } \\
(\mu \mathrm{M})\end{array}$} & \multicolumn{3}{|c|}{$\begin{array}{l}\text { Silicates } \\
(\mu \mathrm{M})\end{array}$} & \multirow{2}{*}{$\begin{array}{l}\text { Mixed } \\
\text { layer } \\
\text { depth } \\
(\mathrm{m})\end{array}$} \\
\hline & 0 & 25 & 50 & 0 & 25 & 50 & 0 & 25 & 50 & 0 & 25 & 50 & 0 & 25 & 50 & \\
\hline Coastal 1 & 25.5 & 18.8 & 15.3 & 34.4 & 34.6 & 34.8 & 4.5 & 7.8 & 10.1 & 0.9 & 0.9 & 1.4 & 10.9 & 14.7 & 32.3 & 7 \\
\hline Coasta & 27.1 & 18.8 & 15.7 & 34.6 & 34.6 & 34.8 & 6.7 & 9.9 & 8.2 & 0.6 & 2.1 & 1.0 & 10.0 & 19.0 & 10.6 & 10 \\
\hline Coastal 3 & 27.5 & 19.5 & 16.3 & 34.6 & 34.6 & 34.8 & 5.1 & 9.3 & 9.6 & 0.5 & 1.2 & 1.3 & 10.8 & 20.7 & 21.1 & 5 \\
\hline Coastal 4 & 27.3 & 19.6 & 15.5 & 34.7 & 34.7 & 34.9 & 9.9 & 10.1 & 10.1 & 0.8 & 1.4 & 1.7 & 28.0 & 33.1 & 31.8 & 14 \\
\hline Coast & 5.4 & 19.8 & 17.1 & 34.6 & 34.6 & 34.7 & 2.1 & 8.6 & 8.5 & 1.0 & 1.7 & 1.3 & 4.1 & 7.6 & 1.1 & 3 \\
\hline Intermediate 1 & 27.5 & 20.6 & 15.2 & 34.6 & 34.6 & 34.9 & 3.9 & 6.4 & 9.5 & 0.7 & 0.9 & 2.6 & 7.0 & 4.9 & 12.4 & 4 \\
\hline & 27.8 & 20.1 & 16.6 & 34.5 & & 34.8 & 9.7 & 10.1 & 10.0 & 0.8 & & 1.4 & 12.7 & 22.9 & & 11 \\
\hline Intermediate 3 & 26.7 & 21.3 & 16.0 & 34.6 & 34.6 & 34.8 & 9.7 & 10.1 & 10.1 & 1.5 & 1.7 & 1.7 & 13.1 & 23.4 & 23.1 & 4 \\
\hline Intermediate 4 & 23.6 & 18.7 & 17.3 & 34.6 & 34.6 & 34.7 & 0.4 & 8.5 & 9.2 & 1.3 & 1.3 & 1.1 & 1.2 & 5.1 & 9.4 & 2 \\
\hline Intermediate 5 & 27.8 & 18.0 & 15.6 & 34.5 & & 34.9 & 2.1 & & 9.9 & 1.4 & 1.5 & 2.4 & 3.0 & 7.2 & 11.7 & 10 \\
\hline Oceanic & 25.8 & 20.7 & 15.9 & 34.3 & 34.3 & 34.5 & 2.8 & 8.8 & 9.6 & 0.4 & 1.1 & 1.4 & 8.9 & 8.01 & 16.0 & 7 \\
\hline Oceanic 2 & 26.6 & 18.1 & 15.4 & 34.5 & 34.6 & 34.7 & 3.9 & 8.1 & 9.1 & 3.3 & 2.5 & 2.3 & 5.5 & 9.19 & 11.9 & 2 \\
\hline & 26.0 & 19.9 & 17.2 & 34.5 & 34. & 34.7 & 2.0 & 9. & 9.5 & 0.5 & 1.4 & 1.3 & 4.1 & 11 & 11.0 & 13 \\
\hline Oceanic 4 & 24.8 & 20.1 & 16.1 & 34.5 & 34.5 & 34.7 & 9.9 & 9.9 & 9.2 & 0.9 & 0.9 & 1.0 & 12.5 & 12.8 & 8.9 & 11 \\
\hline Oceanic 5 & 25.7 & 22.0 & 18.1 & 34.5 & 34.5 & 34.6 & 0.7 & 6.5 & 9.0 & 0.6 & 1.2 & 1.3 & 1.3 & 4.97 & 8.6 & 1 \\
\hline
\end{tabular}
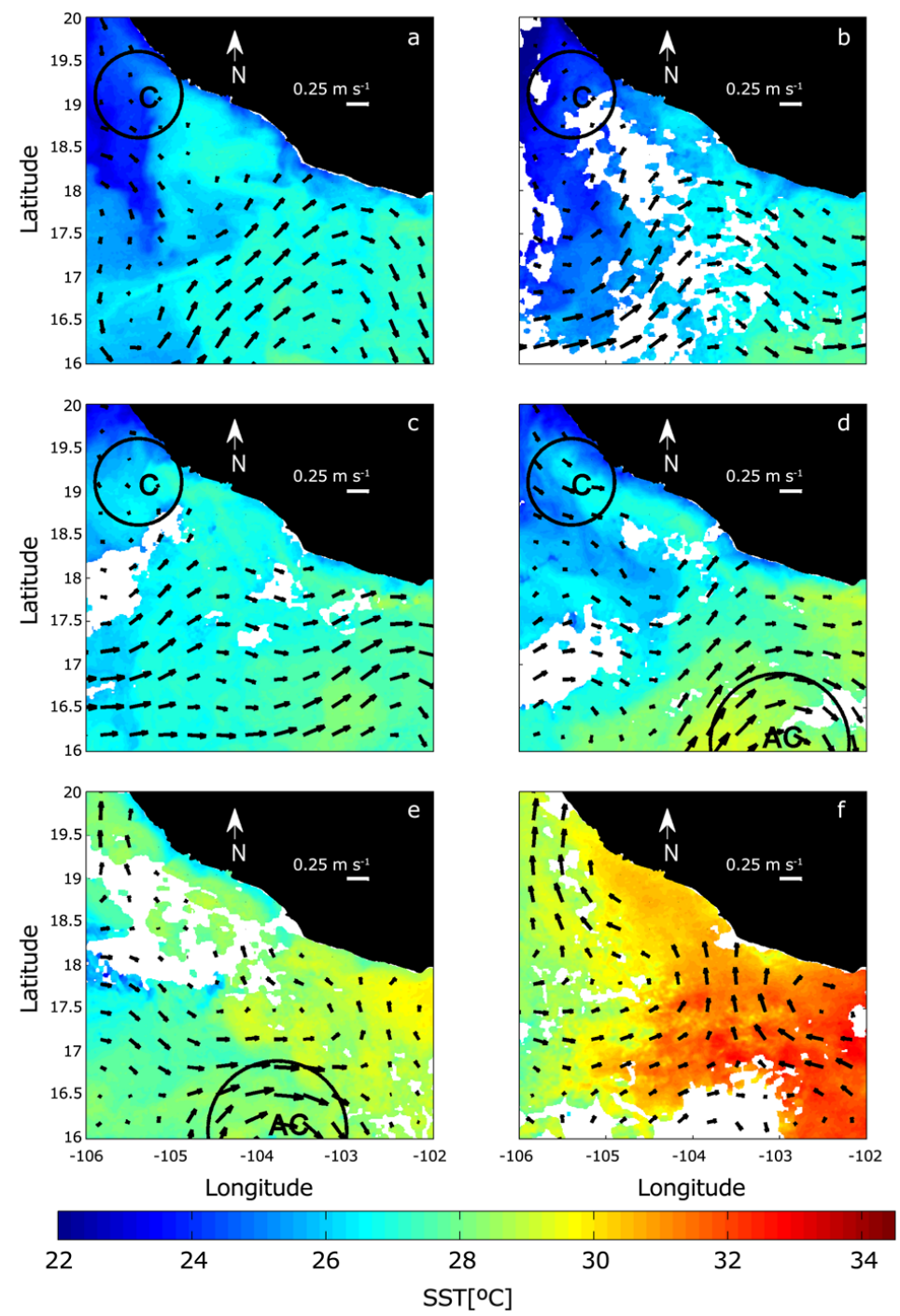

Figure 2. Sea surface temperature recorded by MODIS-Aqua off the Mexican Central Pacific coast during: (a) January, (b) February, (c) March, (d) April, (e) May and (f) June 2011. The arrows indicate the pattern of oceanic geostrophic currents, and the circles show cyclonic/ anticyclonic gyres (white pixels denote unavailable data due to cloud cover) / Temperatura superficial del mar obtenida de MODIS-Aqua en la costa del Pacífico central mexicano durante: (a) enero, (b) febrero, (c) marzo, (d) abril, (e) mayo y (f) junio 2011. Las flechas indican el patrón de las corrientes geostróficas, los círculos muestran los giros ciclónicos/anticiclónicos (pixeles en blanco denotan indisponibilidad de datos debido a cobertura de nubes) 
Figure 3. Sea surface temperature recorded by M ODISAqua off the Mexican Central Pacific coast during: (a) July, (b) August, (c) September, (d) October, (e) November and (f) December 2011. The arrows indicate the pattern of oceanic geostrophic currents, and the circles show cyclonic/ anticyclonic gyres (white pixels denote unavailable data due to cloud cover) / Temperatura superficial del mar obtenida de MODISAqua en la costa del Pacífico central mexicano durante: (a) julio, (b) agosto, (c) septiembre, (d) octubre, (e) noviembre y (f) diciembre 2011. Las flechas indican el patrón de las corrientes geostróficas, los círculos muestran los giros ciclónicos/anticiclónicos (pixeles en blanco denotan indisponibilidad de datos debido a cobertura de nubes)
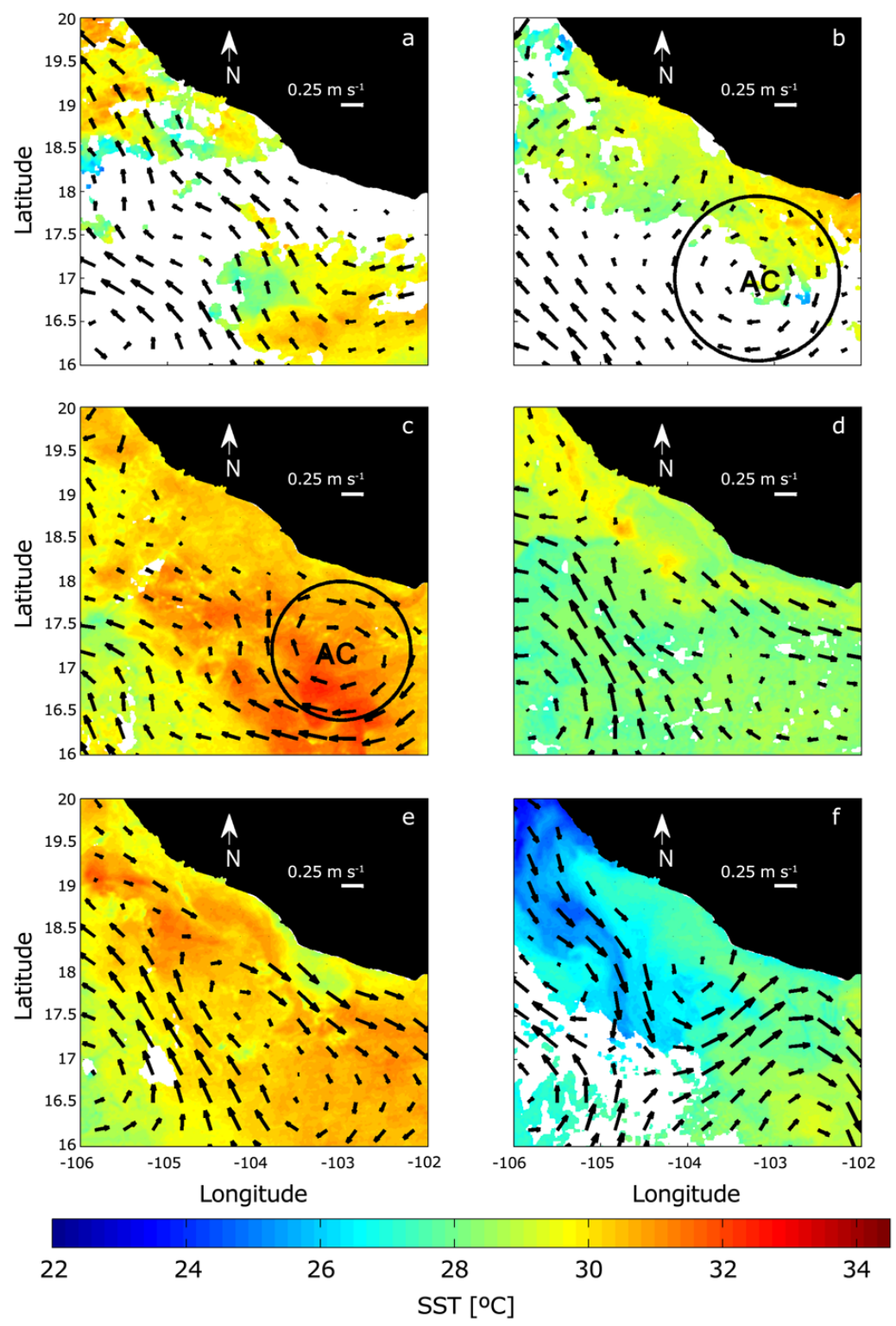

MARINe MaMmal SPECIES RICHNESS AND DISTRIBUTION

over the entire area. Anticyclonic gyres were also observed moving towards the northwest (Figs. 3a and 5a). By the middle of the summer-fall period the geostrophic circulation changed towards the southeast; however, flow direction in the oceanic zone was towards the northwest (Figs. $3 b$ and 5b). The SST oscillated between 30 and $31^{\circ} \mathrm{C}$, and there were Chl- $a$ concentrations of $\sim 3 \mathrm{mg} \mathrm{m}^{-3}$ near the coast (Fig. $5 \mathrm{c}$ ). Towards the end of this period there was a cold water intrusion $\left(24^{\circ} \mathrm{C}\right)$ at the northern area, and the circulation pattern consisted in a southeast flow. There were Chl- $a$ concentrations of $\sim 0.1 \mathrm{mg}$ $\mathrm{m}^{-3}$ near the coast (Figs. 3f and 5f).
Seven marine mammal species were recorded in 188 sightings during coastal surveys. Only four species in 110 sightings occurred during winter season, for a sighting rate of 0.106 sightings $\mathrm{km}^{-1}$. This rate was significantly different from that obtained during the other seasons (spring: $\mathrm{Q}_{11,3}=2.58$, summer: $\mathrm{Q}_{11,3}=1.92$, fall: $\left.\mathrm{Q}_{11,3}=0.93 ; P<0.05\right)$. The species recorded during winter coastal surveys were: Megaptera novaeangliae, Stenella attenuata, Steno bredanensis, and Stenella longirostris (Table 4). The first two species were distributed mainly along the continental shelf edge, and within the bays of Manzanillo(Fig. 6). 

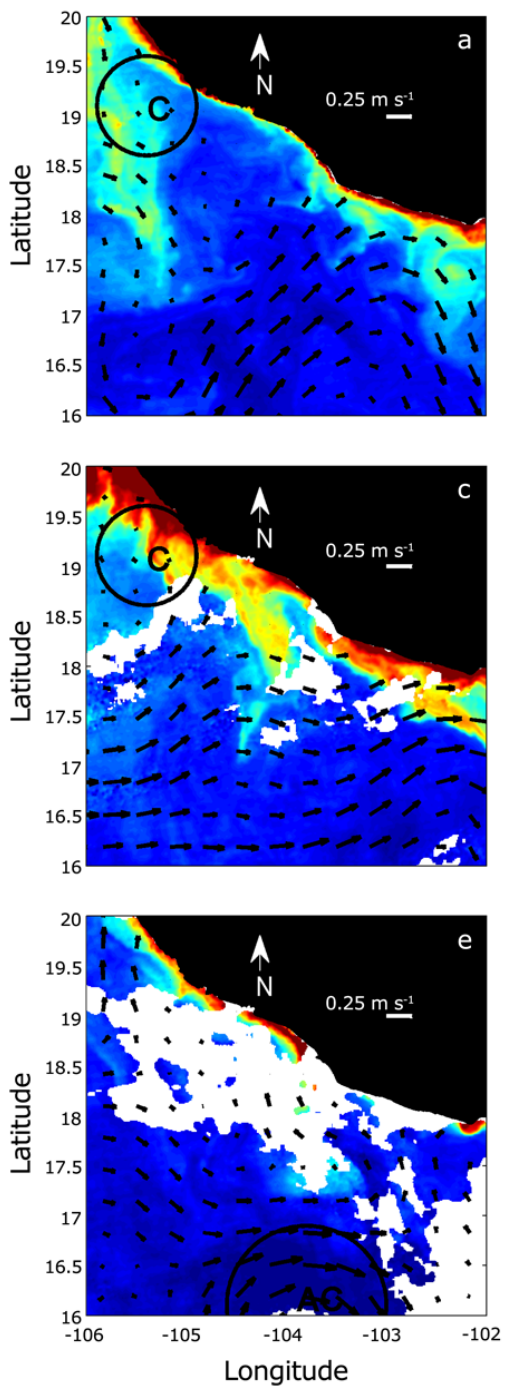

0.1
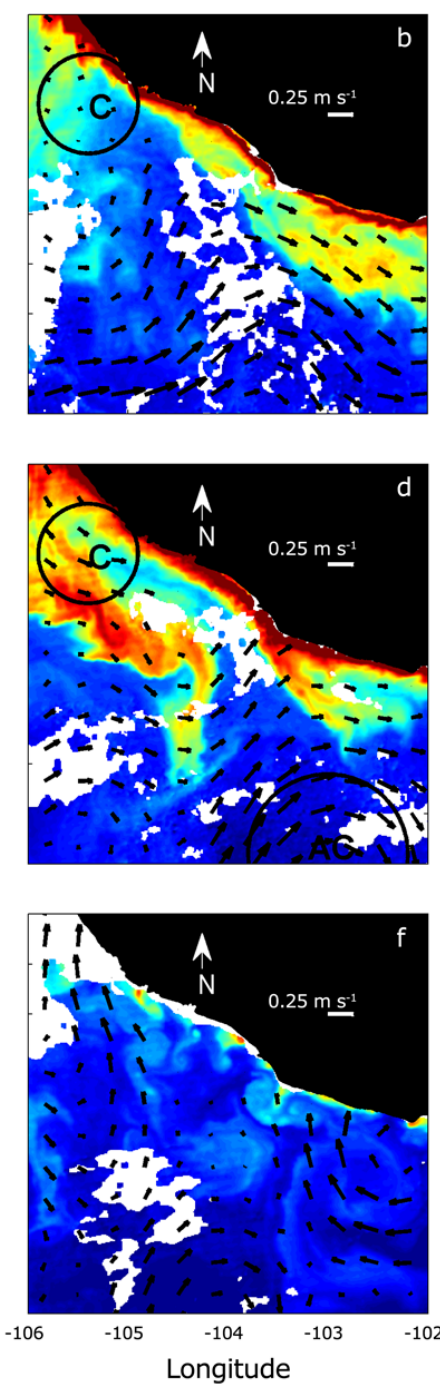

Figure 4. Chlorophyll-a concentration recorded by MODIS-Aqua off the Mexican Central Pacific coast during (a) January, (b) February, (c) March, (d) April, (e) May and (f) June 2011. The arrows indicate the pattern of oceanic geostrophic currents, and the circles show cyclonic/ anticyclonic gyres (white pixels denote unavailable data due to cloud cover) / Concentración de Clorofila-a obtenida de MODIS-Aqua en la costa del Pacífico central mexicano durante: (a) enero, (b) febrero, (c) marzo, (d) abril, (e) mayo y (f) junio 2011. Las flechas indican el patrón de las corrientes geostróficas, los círculos muestran los giros ciclónicos/ anticiclónicos (pixeles en blanco denotan indisponibilidad de datos debido a cobertura de nubes)

A total of 14 sightings corresponding to five species were recorded in the spring season, with a sighting rate of 0.025 sightings $\mathrm{km}^{-1}$ (Table 4). The following species were identified: $M$. novaeangliae, S. attenuata, S. longirostris, Balaenoptera edeni, and T. truncatus. Individuals for first 4 species were sighted mainly near the coast, whereas $T$. truncatus individuals were sighted within Tenacatita Bay in Jalisco (Fig. 6). Balaenoptera edeni was observed only once and therefore it was not possible to calculate a sighting rate (Table 4).

Three species in 19 sightings were recorded during the summer, with a rate of 0.025 sightings $\mathrm{km}^{-1}$ (Table 4). Stenella attenuata and S. bredanensis were sighted at the continental shelf limit near the coast, whereas $T$. truncatus was sighted only in the same bay of Jalisco.

A total of 45 sightings corresponding to 5 species were recorded during the fall, with a rate of 0.047 sightings $\mathrm{km}^{-1}$ (Table 4). The following species were recorded: $S$. attenuata, S. bredanensis, T. truncatus, M. novaeangliae, and Z. californianus; this last species was observed only once and therefore it was not possible to calculate a sighting rate. All species were sighted near the coast of Colima, and only $T$. truncatus was sighted inside Tenacatita Bay (Fig. 6). 
Figure 5. Chlorophyll-a concentration recorded by MODIS-Aqua off the Mexican Central Pacific coast during (a) July, (b) August, (c) September, (d) October, (e) November and (f) December 2011. The arrows indicate the pattern of oceanic geostrophic currents, and the circles show cyclonic/ anticyclonic gyres (white pixels denote unavailable data due to cloud cover) / Concentración de Clorofila-a obtenida de MODIS-Aqua en la costa del Pacífico central mexicano durante: (a) julio, (b) agosto, (c) septiembre, (d) octubre, (e) noviembre y (f) diciembre 2011. Las flechas indican el patrón de las corrientes geostróficas, los círculos muestran los giros ciclónicos/anticiclónicos (pixeles en blanco denotan indisponibilidad de datos debido a cobertura de nubes)
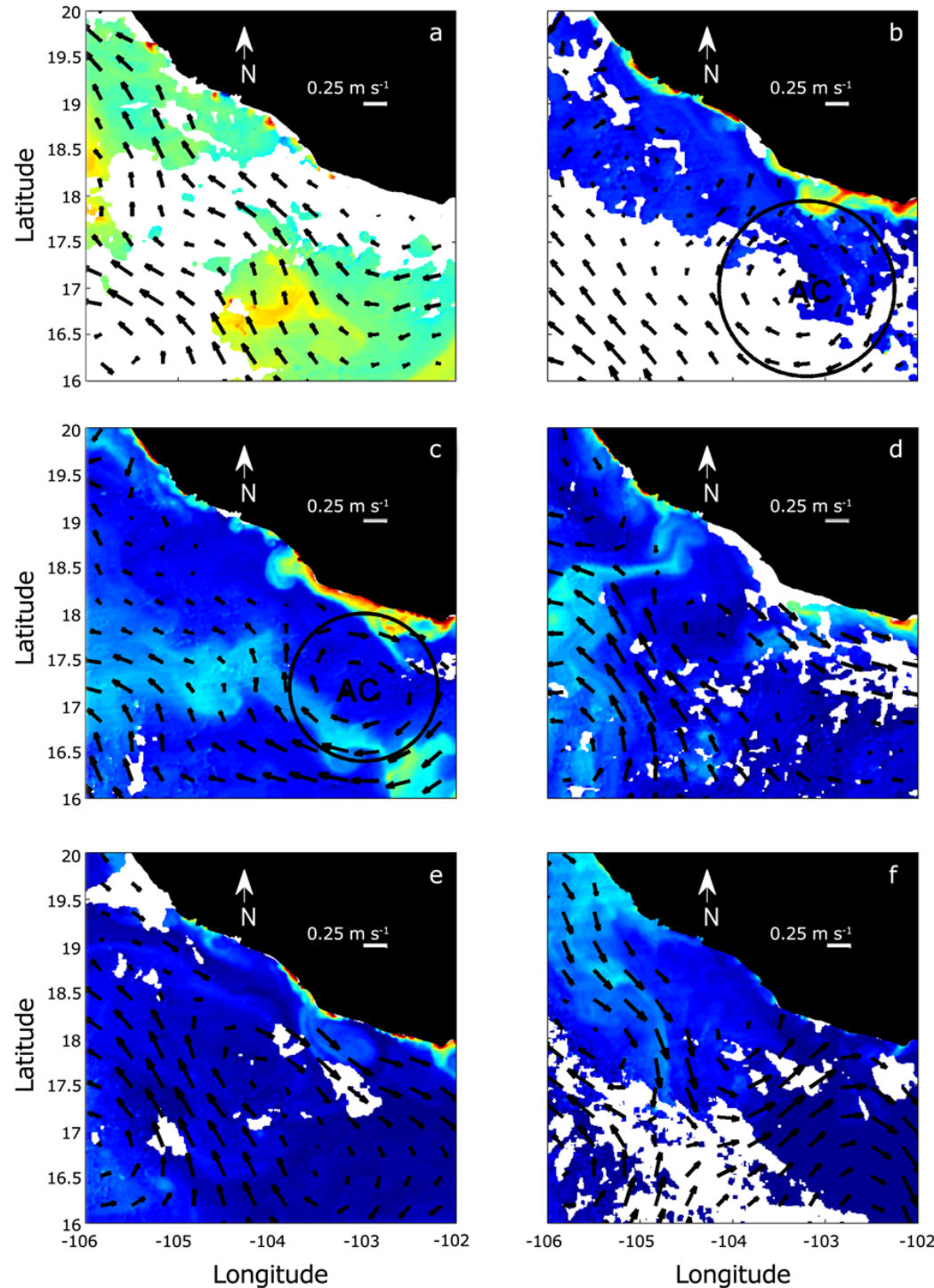

0.1

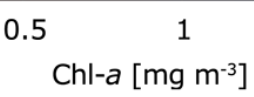

Furthermore, nine marine mammal species were recorded during the moesoscale survey conducted in March 2011, including the seven species recorded during coastal surveys as well as Grampus griseus and Kogia spp. Only once Balaenoptera edeni was observed, and a sighting rate was therefore not calculated for this species. The most sighted species were $M$. novaeangliae $\left(0.012\right.$ sightings $\left.\mathrm{km}^{-1}\right)$ and $S$. attenuata (0.003 sightings km-1) (Table 5). Most M. novaeangliae and S. attenuata sightings occurred near the coast, where SST values were higher than $27^{\circ} \mathrm{C}$. Grampus griseus and Kogia spp. individuals were sighted at the continental shelf edge, where SST was decreasing $\left(26^{\circ} \mathrm{C}\right)$; whereas $S$. longirostris, $S$. bredanensis, and $Z$. californianus individuals were sighted towards the north near the coast in front of a cold current $\left(24^{\circ} \mathrm{C}\right)$ flowing perpendicular to the mainland. Finally, T. truncatus individuals were sighted within Tenacatita Bay (Fig. 7). 


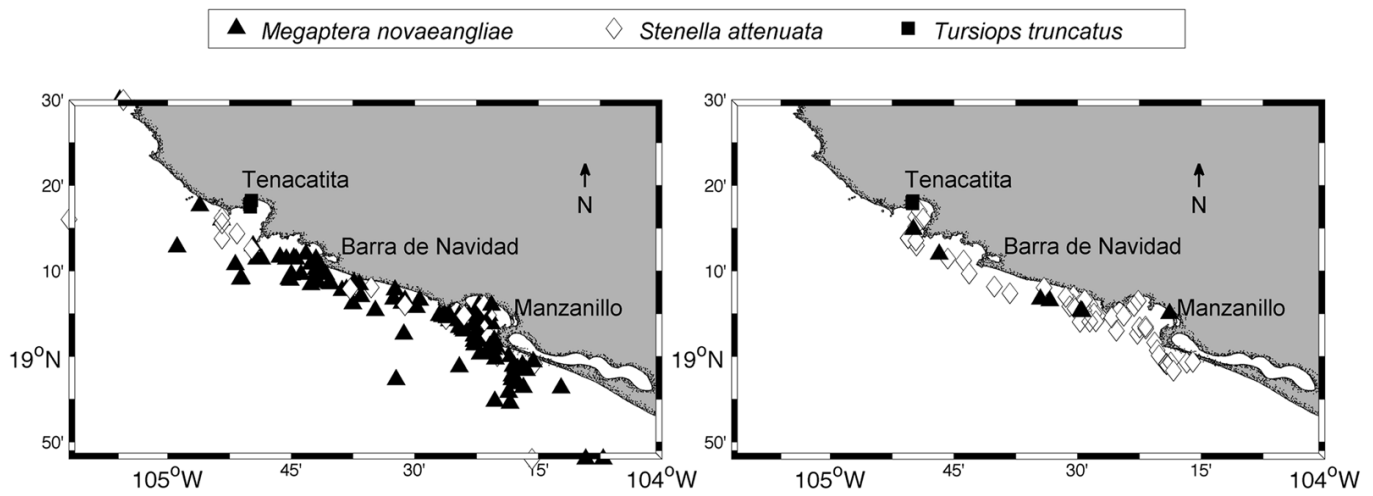

Figure 6. Location of the most frequent marine mammal species into the coastal zone of Mexican Central Pacific during winter-spring (left) and summer-fall (right). Black triangle: Megaptera novaeangliae. White diamond: Stenella attenuata. Black square: Tursiops truncatus / Localización de las especies de mamíferos marinos más frecuentes en la zona costera del Pacífico central mexicano durante invierno-primavera (izquierda) y verano-otoño (derecha). Triángulo negro: Megaptera novaeangliae. Diamante blanco: Stenella attenuata. Cuadrado negro: Tursiops truncatus

Table 4. Sighting rates (SR) of marine mammal species calculated based on surveys conducted from a small boat off the Jalisco-Colima coast during 2011. Total search effort is also included / Rangos de avistamiento (SR) de especies de mamíferos marinos calculados en base a los cruceros en las embarcaciones pequeñas en la costa de Jalisco-Colima durante el 2011. El esfuerzo total también es incluido

\begin{tabular}{lccccc}
\hline & Winter & Spring & Summer & Fall & Total SR \\
\hline Megaptera novaeangliae & 0.092 & 0.009 & - & 0.007 & 0.029 \\
Steno bredanensis & 0.006 & - & 0.003 & 0.002 & 0.003 \\
Stenella attenuata & 0.007 & 0.009 & 0.020 & 0.036 & 0.019 \\
Stenella longirostris & 0.001 & 0.002 & - & - & 0.001 \\
Tursiops truncatus & - & 0.004 & 0.003 & 0.001 & 0.002 \\
Balaenoptera edeni & - & 0 & - & - & - \\
Zalophus californianus & - & - & - & 0 & - \\
Total SR & 0.106 & 0.025 & 0.025 & 0.047 & 0.054 \\
Effort $(\mathrm{km})$ & 859.6 & 560.0 & 758.0 & 934.8 & $3,112.6$ \\
\hline
\end{tabular}

RELATIONSHIP BETWEEN OCEANOGRAPHIC CONDITIONS AND RICHNESS-DISTRIBUTION OF MARINE MAMMAL SPECIES

The PCA analyses based on information from coastal surveys generated two principal components. The first was associated with the bathymetry, which explained $99.63 \%$ of total variance, and the second was associated with Chl- $a$ concentration, which explained $0.20 \%$ of total variance (Fig. 8-left), suggesting that the first component was dominant. A similar result was obtained with the PCA based on information from the mesoscale survey. Two principal components were generated, one of which was associated with bathymetry, and explained $99.5 \%$ of the data variance (Fig. 8-right).
Table 5. Sighting rates(SR) of marine mammal species calculated based on the mesoscale survey (March 2011) in the Mexican Central Pacific region. Total search effort is also included / Rangos de avistamiento (SR) de especies de mamíferos marinos calculados en base al crucero de mesoescala (marzo 2011) en el Pacífico central mexicano. El esfuerzo total también es incluido

\begin{tabular}{lc}
\hline \multicolumn{1}{c}{ Species } & SR \\
\hline Megaptera novaeangliae & 0.012 \\
Steno bredanensis & 0.001 \\
Stenella attenuata & 0.003 \\
Stenella longirostris & 0.001 \\
Tursiops truncatus & 0.001 \\
Kogia spp. & 0.001 \\
Grampus griseus & 0.002 \\
Zalophus californianus & 0.001 \\
Balaenoptera edeni & - \\
Total SR & 0.023 \\
Effort (km) & $1,890.8$ \\
\hline
\end{tabular}




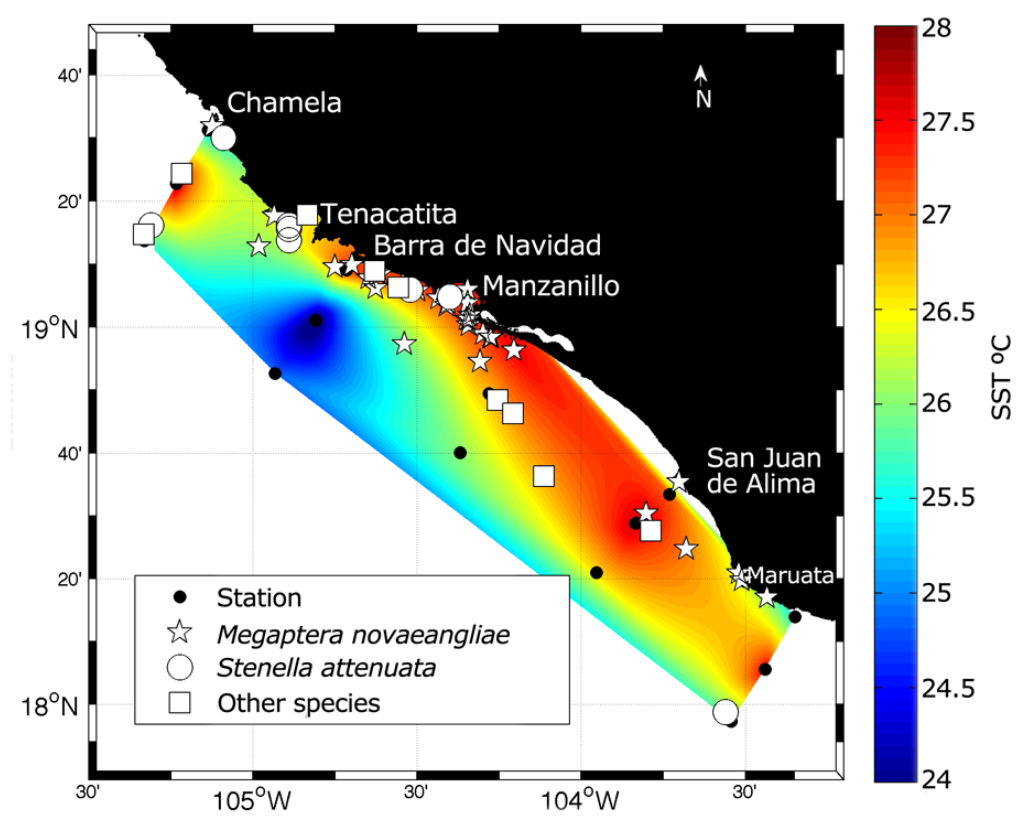

Figure 7. Sea surface temperature and marine mammal distribution observed during the mesoscale survey in March 2011. Other species (S. longirostris, Steno bredanensis, Grampus griseus, Kogia spp., Tursiops truncatus, Zalophus californianus) / Distribución de la temperatura superficial y de mamíferos marinos observada durante el crucero mesoescala en marzo 2011. Otras especies (S. Iongirostris, Steno bredanensis, Grampus griseus, Kogia spp., Tursiops truncatus, Zalophus californianus)
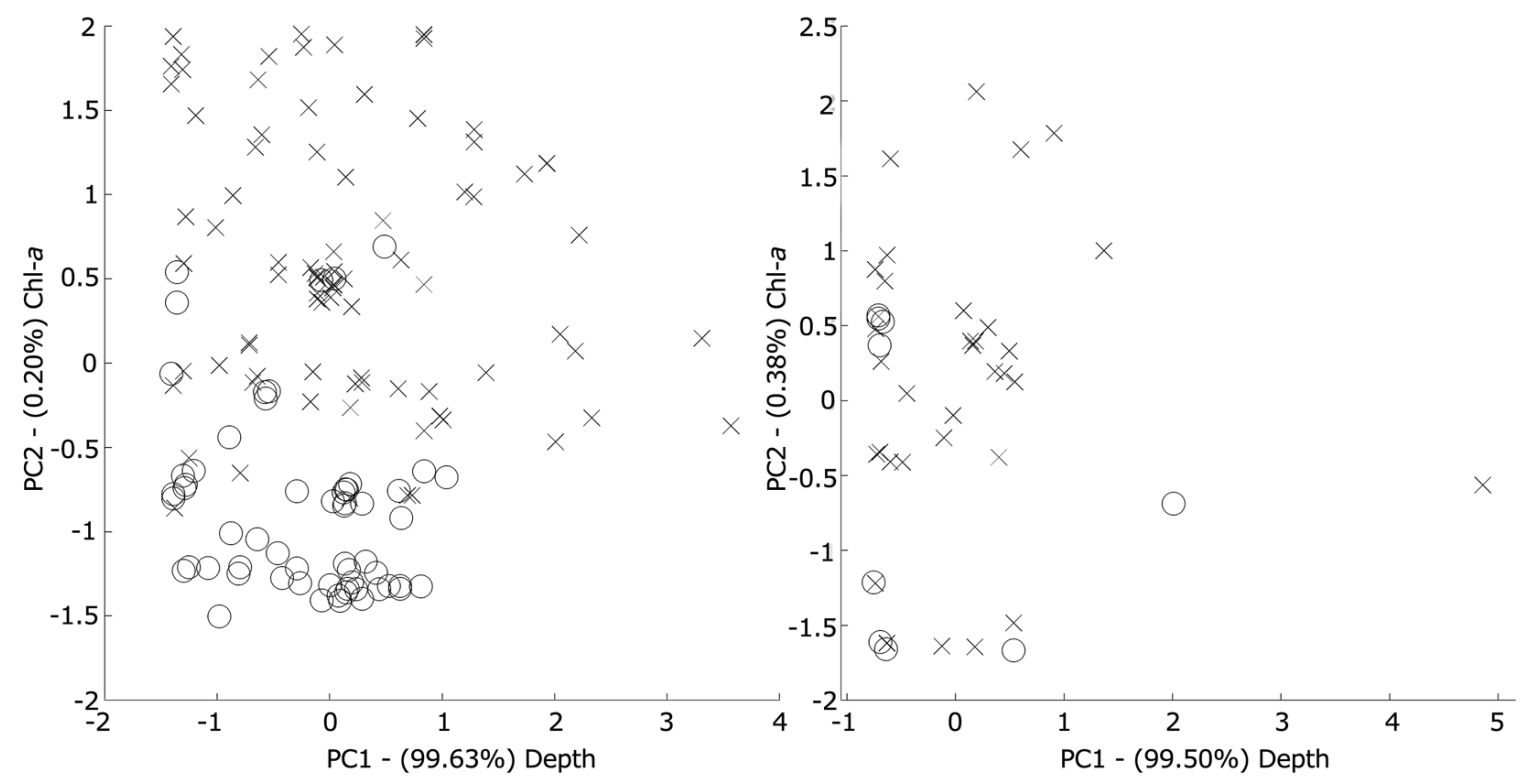

Figure 8. Principal component analysis (PCA) of the oceanographic parameters and the dominant marine mammal species during coastal surveys (left) and the mesoscale survey (right). Crosses: Megaptera novaeangliae. Circles: Stenella attenuata / Análisis de componentes principales (ACP) de los parámetros oceanográficos y las especies dominantes de mamíferos marinos durante los cruceros costeros (izquierda) y el crucero de mesoescala (derecha). Cruces: Megaptera novaeangliae y Círculos: Stenella attenuata 


\section{Discussion}

Oceanographic conditions were similar during winter and spring, and during summer and fall 2011, so that two periods could be defined in the MCP: cold (winter-spring) and warm (summerfall). This oceanographic pattern has been previously described by Filonov et al. (2000). Moreover, this pattern could describe a relationship between habitat characteristics and the distribution of the most frequent (>30 sightings) cetacean species in the MCP region: M. novaeangliae and S. attenuata (Ortega-Ortiz et al. 2011), which had been no described before.

\section{OCEANOGRAPHIC CONDITIONS AND RICHNESS-DISTRIBUTION OF MARINE MAMMAL SPECIES DURING THE COLD PERIOD (WINTER-SPRING)}

The presence of the $\mathrm{CC}$ was observed during this period, with cold waters $\left(<22^{\circ} \mathrm{C}\right)$ flowing from the north. The influence of the CC has been reported in this area by several authors (Fiedler \& Talley 2006, Lavín et al. 2006b, López-Sandoval et al. 2009). The SST images and geostrophic currents indicated several MDS, mainly cyclonic gyres (Figs. 2 and 4), which had previously been reported as the main fertilizing processes propagating near the continental shelf $(200 \mathrm{~m})$ in this region of the MCP (Salas et al. 2006, Pantoja et al. 2012). The MDS could have resulted in the lifting/sinking ( $20 \mathrm{~m})$ of isotherms, allowing cold-water intrusion towards the surface, as has been described by some authors (e.g., Torres-Orozco et al. 2005, Salas et al. 2006, López-Sandoval et al. 2009). Although gyres could not be clearly identified by AVISO data within the study area (due to the $1 / 3^{\circ}$ data resolution); however, the SST and Chl- $a$ satellite data were useful to identified some of these structures that have been described during the entire year. They were formed as the result of the interactions among continental inputs, coastal circulation, and marine topography (Galicia-Pérez et al. 2006, Salas et al. 2006).

The MDS have been reported to affect characteristics of the water column such as mixed layer depth and inorganic nutrient distribution (Arístegui et al. 2003, Salas et al. 2006, Rennie et al. 2009). The main forcing agents that could generate variations in the mixed layer depth are differences in wind intensity, and differences in current intensity (such as the CC and MCC), as has been reported by Linacre et al. (2010). However, given that there are no data on wind intensity in the study area for 2011, we hypothesize that wind intensity was probably low, and therefore a mixed layer was formed at $\sim 10 \mathrm{~m}$ depth.
Inorganic nutrient concentrations were high below the mixed layer (25 and $50 \mathrm{~m}$ depth, Table 2 ), which could have resulted from transport (gyres and upwellings) towards the subsurface (Martin \& Richards 2001), and from variations in nutrient concentrations resulting from phytoplankton consumption (Falkowski 1997). The high Chl- $a$ values recorded suggest a fertilization event in the area, which could have been caused by the shoaling of the thermocline associated with cyclonic gyres (Fig. 4). These results coincide with those reported by LópezSandoval et al. (2009), who characterized this period as productive because that is when maximum values of primary productivity and Chl- $a$ occur, and it is also when sunlight and oceanographic conditions are favorable for phytoplankton growth.

Another factor that could have influenced the presence of cold waters in the northern part of the study region (Fig. 2a-d) is the occurrence of upwelling events such as those that have been reported near Cabo Corrientes during the winter-spring period (Filonov et al. 2000, Torres-Orozco et al. 2005, Kessler 2006, López-Sandoval et al. 2009). The NOAA upwelling index ${ }^{5}$ for this period suggests an upwelling event, with cold water being transported by winds and marine currents from the northwest, as has been described by Fiedler \& Talley (2006). Additionally, the already-mentioned geostrophic circulation pattern could have favored the formation of gyres in the study area. These gyres could have had repercussions on nutrient and Chl- $a$ concentrations, as was explained previously. This pattern was observed in the SST and Chl- $a$ images, with concentrations above $10 \mathrm{mg} \mathrm{m}^{-3}$ near the coast, coinciding with high nutrient values (>20 $\mu \mathrm{M})$ (Figs. 2 and 4).

The species richness recorded during winter-spring period in coastal surveys was relatively constant; however, a higher richness was recorded during the mesoscale survey possibly because a wider region was surveyed and species with oceanic habits were also sighted (i.e., Kogia spp. and Grampus griseus). Some of these species have also been associated with template environments (i.e., Stenella longirostris, Kogia spp. and Zalophus californianus) due to the temperature effects on prey distribution (Davis et al. 2002), and therefore no sightings would be expected during other periods.

The sighting rate calculated based on coastal surveys compared with the sighting rate obtained based on data from the mesoscale survey constitutes evidence that the coastal area is the most important habitat for the distribution of these species, mainly for M. novaeangliae, the most sighted species during the winter season (Table 4).

${ }^{5}<\mathrm{ftp}$ ://orpheus.pfeg.noaa.gov/outgoing/upwell/monthly/upindex.mon> 
Studies on M. novaeangliae distribution report that this species uses areas with similar characteristics to those of the MCP to carry out breeding and calving activities, because warm temperatures $\left(\sim 28^{\circ} \mathrm{C}\right)$ allow calves to thermoregulate, and the presence of semi-enclosed coastal bodies and shallow depths provide calves with protection from predators (Calambokidis et al. 2001, Rasmussen et al. 2011).

The oceanographic conditions recorded during this study suggest that several potential cetacean prey (zooplankton, fish, squid, among others) could have been transported to the area (Franco-Gordo et al. 2004, León-Chávez et al. 2010). Megaptera novaeangliae individuals could have been feeding opportunistically in the area, as has already been reported for nearby regions such as the Gulf of California (Gendron \& Urbán 1993) and the Oaxaca coast (Villegas-Zurita \& CastillejosMoguel 2013). However, the most commonly recorded behavioral activities of this species in the region have been associated with breeding (García-Valencia 2016).

The second most frequently sighted species during the cold period was $S$. attenuata. This species was distributed near the coast, which resulted in a high correlation between its density and bathymetry. It has been reported that this species has an affinity for tropical waters with a deep thermocline $(\sim 40 \mathrm{~m})$ (Reilly 1990) and is distributed in areas with shallow depths that are used for resting, feeding, and finding refuge (Forcada 2002), as was seen in the present study.

The sighting rates of other odontocete species were lower, indicating that their presence off the Jalisco and Colima coast could be associated with ecological aspects similar to those affecting S. attenuata. It is also possible that these species use the region as a transit area on their way to other regions of the Pacific Ocean with the exception of T. truncatus, which were observed in Tenacatita Bay, during all sampling period. Even, repeated observations on the same individuals suggesting that this could be a resident pod (Rossbach \& Herzing 1999). This is a common characteristic for this species that had been reported in other sites (e.g., Sellas et al. 2005, Galindo 2007, Vázquez-Castán et al. 2007, Martínez-Serrano et al. 2011). However, similar survey effort is needed during other periods to explain the ecology of these species.

\section{OCEANOGRAPHIC CONDITIONS AND DISTRIBUTION- RICHNESS OF MARINE MAMMAL SPECIES DURING THE WARM PERIOD (SUMMER-FALL)}

The oceanographic conditions during this period could have been due to an increase in solar radiation and to the advection of heat from the MCC in the equatorial region (Filonov et al. 2000). This pattern is caused by a weakening of the northwesterly winds; this allows the MCC to flow northwards, transporting warm waters $\left(29-30^{\circ} \mathrm{C}\right)$ from the North Equatorial Current (e.g., TPSW) (Wyrtki 1967) and unproductive waters from the Gulf of Tehuantepec (Gonzalez-Silvera et al. 2004, Fiedler \& Talley 2006, Kessler 2006). The MCC created MDS which could be seen in the SST and Chl- $a$ images (Figs. 2 and 3 ), and influenced the availability of these parameters.

The temperature was homogeneous along the water column due to the presence of anticyclonic gyres. These oceanographic systems resulted in the sinking of isotherms, and in the mixing of the upper meters of the water column (Arístegui et al. 2003). The detection of gyres near the coast was difficult due to the resolution of geostrophic data $(\sim 20 \mathrm{~km})$. On the other hand, the presence of internal waves, which have been reported in this area (Filonov et al. 2000) near the continental shelf, could have resulted in the sinking of isotherms and could have contributed in this way to a non-stratified water column near the coast. The low salinity values recorded in the study area during the warm period are related to continental discharge from the coastal zone (Olivos-Ortiz et al. 2008). The rainy season occurs between June and October; this is the period when tropical storms pass through the area (Servicio Meteorológico Nacional, México) ${ }^{6}$.

The variations in nutrient and Chl- $a$ concentrations during this period could have been influenced by the already-mentioned temperature increase (up to $30^{\circ} \mathrm{C}$ at the surface) associated with the transport of less productive waters. Temperature is an abiotic factor that is crucial for phytoplankton growth and nutrient assimilation. Values above $28^{\circ} \mathrm{C}$ inhibit phytoplankton growth (Rhee \& Gothan 1981, Neori \& Holm-Hansen 1982). This suggests that low Chl- $a$ concentrations were due to low primary productivity caused by the temperature increase, which coincides with what was reported by López-Sandoval et al. (2009), who found low primary productivity associated with warm tropical waters such as the TPSW during this period. Nutrient concentrations, mainly of phosphates, were high (>2 $\mu \mathrm{M}$ ) during the middle of the warm period (Table 1). This was linked to the beginning of the rainy season, when continental inputs contain higher nutrient concentrations, and partly to the vertical flow from the bottom to the subsurface due to the passage of storms and hurricanes (such as 'Jova', Lujano-Bravo \& Hernández-Unzón 2011). These meteorological events have been identified as mechanisms that cause ascending flow in the water column, resulting in temporal upwelling (Davis \& Yan 2004, Walker et al. 2005).

\footnotetext{
${ }^{6}<$ http://smn.cna.gob.mx/>
} 
The lowest marine mammal species richness was recorded during summer; however, an increase in species richness occurred during fall, which suggests that conditions were similar to winter conditions. The sighting rate increased to 0.047 sightings $\mathrm{km}^{-1}$, mainly of $S$. attenuata, coinciding with the later period of higher temperatures and deeper thermocline $(\sim 30 \mathrm{~m})$, which are optimal conditions for feeding activities. Stenella attenuata feeds on a wide variety of fish (27 families), on cephalopods (17 families), and on some decapods (Galatheidae) (Perrin 2002). Some pelagic and reef fish species also spawn during this period (Silva-Segundo et al. 2006). These could be potential prey and the area could serve as a feeding area (MayCollado \& Forcada 2012). It has been reported that the abundance of $S$. attenuata increased during the period of low water levels at the end of the rainy season in Costa Rica in the Gulf of Papagayo, when coastal upwellings also occurred, because abundance decreased significantly during the remainder of the year (May-Collado \& Forcada 2012). This pattern could be similar to what has already been described about intermittent upwellings in our study area.

Megaptera novaeangliae individuals were recorded at the end of this period, coinciding with the transition phase towards winter. The recorded temperatures of $26-27^{\circ} \mathrm{C}$ could have favored their presence in this area to carry out reproductive activities during the next cold period (Calambokidis et al. 2001). In another hand, sightings of T. truncatus during this period confirmed its potential residence in Tenacatita Bay. Other cetacean species such as $S$. longirostris were not sighted during this warmer period, probably because their occurrence is related with environmental changes from the region.

In summary, the dynamics of the MCP region created favorable oceanographic conditions that allowed the aggregation of marine mammals mainly during the cold period to conduct feeding activities (by dolphins), and breeding activities (particularly by $M$. novaeangliae). However, it is important to keep in mind that the year 2011 was atypical because it was influenced by the cold phase of ENSO (La Niña) ${ }^{7}$; and probably our described relationship could be biased. Therefore, more research must to be conducted during a year with typical oceanographic conditions or over a longer period, to corroborate if the depth of the study area is the only parameter that determined species richness and distribution of marine mammals in the MCP region.

\footnotetext{
${ }^{7}<$ www.cpc.ncep.noaa.gov/products/analysis_monitoring/ ensostuff/ensoyears.shtml>
}

\section{ACKOWLEDGMENTS}

This bachelor research was possible by the Programa de Mejoramiento al Profesorado PROMEP-SEP and Comisión Federal de Electricidad for funding marine mammal surveys in the region; the Facultad de Ciencias Marinas y Centro Universitario de Investigaciones Oceanológicas of Universidad de Colima (U. de C.) for logistical support; the Secretaría de Medio Ambiente y Recursos Naturales through the Dirección General de Vida Silvestre Mexico for providing the SGPA/ DGVS/00447/11 permit for field research. To the Mary Chuy III crew and captains Oscar Enciso and Ivan Livas, besides the students of the Grupo Universitario de Investigación de Mamíferos Marinos (GUIMM) of the U. de C. and volunteers for the support in the field.

\section{LITERATURE CITED}

Arístegui J, ED Barton, MF Montero, M Muñoz-García \& J Escánez. 2003. Organic carbon distribution and water column respiration in the NW Africa-Canaries Coastal Transition Zone. Aquatic Microbial Ecology 33: 289-301.

Ballance LT, RL Pitman \& PC Fiedler. 2006. Oceanographic influences on seabirds and cetaceans of the eastern tropical Pacific: A review. Progress in Oceanography 69: 360-390.

Bräger S, JA Harraway \& BFJ Manly. 2003. Habitat selection in a coastal dolphin species (Cephalorhynchus hectori). Marine Biology 143: 223-244.

Calambokidis J, GH Steiger, JM Straley, LM Herman, S Cerchio, DR Salden, JR Urbán, JK Jacobsen, OV Ziegesar, KC Balcomb, CM Gabriele, ME Dahlheim, S Urchida, G Ellis, Y Miyamura, P Ladrón de Guevera, M Yamaguchi, F Sato, SA Mizroch, L Schlender, K Rasmussen, J Barlow \& TJQ Li. 2001. Movements and population structure of humpback whales in the North Pacific. Marine Mammal Science 17: 769-794.

Clarke KR \& RM Warwick. 2001. Change in marine communities: An approach to statistical analysis and interpretation, 144 pp. Plymouth Marine Laboratory, Plymouth.

Danil K \& SJ Chivers. 2006. Habitat based spatial and temporal variability in life history characteristics of female common dolphins (Delphinus delphis) in the eastern Tropical pacific. Marine Ecology Progress Series 318: 277-286.

Davis A \& X-H Yan. 2004. Hurricane forcing on chlorophyll-a concentration off the northeast coast of the U.S. Geophysical Research Letters 31: 1-4.

Davis RW, JG Ortega-Ortiz, CA Ribic, WE Evans, DC Biggs \& PH Ressler. 2002. Cetacean habitat in the northern oceanic Gulf of Mexico. Deep Sea Research I 49: 121-142. 
Falkowski P. 1997. Evolution of the nitrogen cycle and its influence on the biological sequestration of $\mathrm{CO}_{2}$ in the ocean. Nature 387: 272-275.

Fiedler PC \& LD Talley. 2006. Hydrography of the eastern tropical Pacific: A review. Progress in Oceanography 69: 143-180.

Filonov AE, IE Tereshchenko, CO Monzòn, ME GonzálezRuelas \& E Godínez-Domínguez. 2000. Variabilidad estacional de los campos de temperatura y salinidad en la zona costera de los estados de Jalisco y Colima, México. Ciencias Marinas 26(2): 303-321.

Forcada J. 2002. Distribution. In: Perrin WF, B Würsig \& JGM Thewissen (eds). Encyclopedia of marine mammals, pp. 327333. Academic Press, San Diego.

Franco-Gordo C, E Godínez-Domínguez, AE Filonov, IE Tereshchenko \& J Freire. 2004. Plankton biomass and larval fish abundance prior to and during the El Niño period of 1997-1998 along the central Pacific coast of México. Progress in Oceanography 63: 99-123.

Galicia-Pérez M, J Gaviño-Rodríguez, E Torres-Orozco \& M Sánchez-Barajas. 2006. Condiciones hidrológicas y de circulación en el litoral de Colima durante el año 2002. En: Jiménez-Quiroz MDC \& E Espino-Barr (eds). Los recursos pesqueros y acuícolas de Jalisco, Colima y Michoacán, pp. 41-50. Manzanillo, Colima.

Galindo JA. 2007. Diversidad, distribución y abundancia de los mamíferos marinos en la zona costera norte-centro del estado de Veracruz, México. Tesis de Licenciatura, Universidad Veracruzana, México, $71 \mathrm{pp}$.

García-Valencia RX. 2016. Uso de hábitat, movimientos y fidelidad al sitio de las agrupaciones de ballena jorobada (Megaptera novaeangliae) en la costa del Pacífico Central Mexicano (2010-2013). Tesis de Licenciatura, Facultad de Ciencias Marinas, Universidad de Colima, 79 pp.

Gendron D \& JR Urbán. 1993. Evidence of feeding by humpback whales (Megaptera novaeangliae) in the Baja California breeding ground, México. Marine Mammal Science 9: 76-81.

Gonzalez-Silvera A, E Santamaría-del-Angel, R MillanNuñez \& H Manzo-Monroy. 2004. Satellite observations of mesoscale eddies in the Gulfs of Tehuantepec and Papagayo (Eastern Tropical Pacific). Deep-Sea Research II 51:587-600.

Grasshoff K, M Ehrhardt \& K Kremling. 1983. Methods of seawater analysis, 419 pp. Verlag Chemie, New York.

Hastie GD, B Wilson \& PM Thompson. 2003. Fine-scale habitat selection by coastal bottlenose dolphins: application of a new land-based video montage technique. Canadian Journal of Zoology 81: 469-478.

Kessler WS. 2006. The circulation of the eastern tropical Pacific: A review. Progress in Oceanography 69: 181-217.
Kiszka J, K Macleod, O Van-Canneyt, D Walker \& V Ridoux. 2007. Distribution, encounter rates, and habitat characteristics of toothed cetaceans in the Bay of Biscay and adjacent waters from platform-of-opportunity data. Marine Science 64(5): 1033-1043.

Laptikhovsky V. 2009. Oceanographic factors influencing the distribution of South American fur seal, Arctocephalus australis around the Falkland Islands before the breeding season. Journal of the Marine Biological Association of the United Kingdom 89(9): 1597-1600.

Lavín MF, PC Fiedler, JA Amador, LT Ballance, J FärberLorda \& AM Mestas-Núñez 2006a. A review of eastern tropical Pacific oceanography: Summary. Progress in Oceanography 69(2-4): 391-398.

Lavín MF, E Beier, J Gomez-Valdes, VM Godínez \& J García. 2006b. On the summer poleward coastal current off SW México. Geophysical Research Letters 33(L02601): $1-4$.

León-Chávez CA, L Sánchez-Velasco, E Beier, MF Lavín, VM Godínez \& J Färber-Lorda. 2010. Larval fish assemblages and circulation in the Eastern Tropical Pacific in autumn and winter. Journal of Plankton Research 32(4): $397-410$.

Linacre L, R Durazo, JM Hernández-Ayón, F DelgadilloHinojosa, G Cervantes-Díaz, JR Lara-Lara, V Camacho-Ibar, A Siqueiros-Valencia \& C BazánGuzmán. 2010. Temporal variability of the physical and chemical water characteristics at a coastal monitoring observatory: Station ENSENADA. Continental Shelf Research 30(16): 1730-1742.

López-Sandoval DC, JR Lara-Lara, MF Lavín, S ÁlvarezBorrego \& G Gaxiola-Castro. 2009. Primary productivity in the eastern tropical Pacific off Cabo Corrientes, Mexico. Ciencias Marinas 35(2): 169-182.

Lujano-Bravo C \& A Hernández-Unzón. 2011. Reseña del huracán «Jova» del Océano Pacífico. Coordinación General del Servicio Meteorológico Nacional/Temporada 2011 de Ciclones Tropicales, < http://smn.cna.gob.mx/tools/DATA/ Ciclones\%20Tropicales/Ciclones/2011-Jova.pdf>.

Martin AP \& KJ Richards. 2001. Mechanisms for vertical nutrient transport within a North Atlantic mesoscale eddy. Deep Sea Research Part II: Topical Studies in Oceanography 48(4/5): 757-773.

Martínez-Serrano I, A Serrano, G Heckel \& Y Schramm. 2011. Distribución y ámbito hogareño de toninas (Tursiops truncatus) en Veracruz, México. Ciencias Marinas 37(4): 379-392.

May-Collado LJ \& J Forcada. 2012. Small-scale estimation of relative abundance for the coastal spotted dolphins (Stenella attenuata) in Costa Rica: the effect of habitat and seasonality, Revista de Biología Tropical 60(2): 133-142. 
Moore SE. 2008. Marine mammals as ecosystem sentinels. Journal of Mammalogy 89(3): 534-540.

Neori A \& O Holm-Hansen. 1982. Effect of temperature on rate of photosynthesis in Antarctic phytoplankton. Polar Biology 1(1): 33-38.

Olivos-Ortiz A, R Sosa-Avalos, E Torres-Orozco, L SilvaIñiguez, M Galicia-Pérez \& J Gaviño-Rodríguez. 2008. Influencia de las descargas de agua continental en la concentración de nutrientes en las bahías de Santiago y Manzanillo, Colima. Iridia 5: 6-15.

Ortega-Ortiz CD, AE Juárez-Ruiz \& A Olivos-Ortiz. 2011. Riqueza y distribución espacio-temporal de mamíferos marinos y su relación con la temperatura de la columna de agua, en el Pacífico Central Mexicano. In: Chávez-Comparán JC \& J Mimbela-López (eds). Avances sobre investigaciones marinas y acuícolas del Pacífico Tropical Mexicano, pp. 128149. Universidad de Colima, México.

Ortega-Ortiz CD, ER Díaz-Torres, AE Juárez-Ruiz \& MJ Hernández-Dueñas. 2013. Cetáceos de la costa de Jalisco, Colima y Michoacán. In: Godinez Domínguez E \& C FrancoGordo (eds). Inventario de Biodiversidad de la costa sur de Jalisco y Colima. Volumen 2: 133-143. Universidad de Guadalajara, México.

Pantoja DA, SG Marinone, A Parés-Sierra \& F GómezValdivia. 2012. Modelación numérica de la hidrografía y circulación estacional y de mesoescala en el Pacífico central mexicano. Ciencias Marinas 38(2): 363-379.

Pardo MA, N Silverberg, D Gendron, E Beier \& DM Palacios. 2013. Role of environmental seasonality in the turnover of a cetacean community in the southwestern Gulf of California. Marine Ecology Progress Series 487(1): 245260.

Perrin WF. 2002. Pantropical spotted dolphin, Stenella attenuata. In: Perrin WF, B Würsig \& JGM Thewissen (eds). Encyclopedia of marine mammals, pp 819-821. Academic Press, San Diego.

Rasmussen K. J Calambokidis \& GH Steiger. 2011. Distribution and migratory destinations of humpback whales off the Pacific coast of Central America during the boreal winters of 1996-2003. Marine Mammal Science 28(3): 267279.

Reilly SB. 1990. Seasonal changes in distribution and habitat differences among dolphins in the eastern tropical Pacific. Marine Ecology Progress Series 68(9052): 1-11.

Rennie S, CE Hanson, RD McCauley, C Pattiaratchi, C Burton, J Bannister, C Jenner \& MN Jenner. 2009. Physical properties and processes in the Perth Canyon, Western Australia: Links to water column production and seasonal pygmy blue whale abundance. Journal of Marine System 77(1-2): 21-44.
Rhee GY \& IJ Gothan. 1981. The effect of environmental factors on phytoplankton growth: temperature and the interactions of temperature with nutrient limitation. Limnology and Oceanography 26: 647-648.

Rossbach KA \& DL Herzing. 1999. Inshore and offshore bottlenose dolphin (Tursiops truncatus) communities distinguished by association patterns near Grand Bahama Island, Bahamas. Canadian Journal of Zoology 77: 581-592.

Salas J, D Gomis, A Olivos-Ortiz \& G García-Uribe. 2006. Seasonal hydrodynamical features on the shelf of Colima (west coast of Mexico). Scientia Marina 70(4): 719-726.

Salvadeo CJ, A Gómez-Gallardo, D Lluch-Belda \& J UrbánRamírez. 2009. The Odontocete community and its environment in the southwestern Gulf of California. Latin America Journal of Aquatic Mammals 7(1-2): 23-32.

Sellas AB, RS Wells \& PE Rosel. 2005. Mitochondrial and nuclear DNA analyses reveal fine scale geographic structure in bottlenose dolphins (Tursiops truncatus) in the Gulf of Mexico. Conservation Genetics 6: 715-728.

Silva-Segundo C, R Rodríguez-Funes, EV Robles-Jarero \& E Ríos-Jara. 2006. Ictioplancton en las bahías de Chamela, Jalisco y Manzanillo, Colima (ciclo 2001-2002). En: Jiménez-Quiroz MDC \& E Espino-Barr (eds). Los recursos pesqueros y acuícolas de Jalisco, Colima y Michoacán, pp. 266-280, Manzanillo, Colima.

Talley LD, GL Pickard, WJ Emery \& JH Swift. 2011. Ocean dimensions, shapes, and bottom materials. In: Talley LD, GL Pickard, WJ Emery \& JH Swift (eds). Descriptive physical oceanography, pp. 7-27, Academic Press, London.

Torres-Orozco E, A Trasviña, A Muhlia-Melo \& S OrtegaGarcía. 2005. Mesoscale dynamics and yellowfin tuna catches in the Mexican Pacific. Ciencias Marinas 31(4): 671683.

Vázquez-Castán L, A Serrano-Solís, M López-Ortega, JA Galindo, MP Valdés-Arrellanes \& C Naval-Ávila. 2007. Caracterización del hábitat de dos poblaciones de toninas (Tursiops truncatus, Montagu 1821) en la costa Norte del estado de Veracruz, México. Revista Científica UDO Agrícola 7(1): 285-292.

Villegas-Zurita F \& F Castillejos-Moguel. 2013. Primer registro de alimentación oportunista de ballena jorobada (Megaptera novaeangliae) en la costa de Oaxaca, México. Therya 4(1): 113-119.

Walker ND, RR Leben \& S Balasubramanian. 2005. Hurricane-forced upwelling and chlorophyll a enhancement within cold-core cyclones in the Gulf of Mexico. Geophysical Research Letters 32: 1-5.

Wyrtki K. 1967. Circulation and water masses in the eastern equatorial Pacific Ocean. International Journal of Oceanology and Limnology 1(2): 117-147. 